costs by as much as one-third if it moved to such a system, Rachlis adds. "It's much cheaper to administer single-payer plans."

Still, many Obama supporters dream of such a system.

After watching her father's battle with cancer, Jackson's 21-year-old daughter, Elise, believes that time has come. "There is a huge portion of the population that is underinsured and uninsured," the nursing student says. "What kind of society do we live in if that's okay?"

Yet, even if universality isn't adopted, many believe some changes are inevitable.

Obama appears committed to importing more lower-cost generic drugs to the US, a move that's projected to save consumers $\$ 30$ billion while doubtless distressing brand-name pharmaceutical firms.

$\mathrm{He}$ is also proposing to authorize the federal government to negotiate bulk prescription-drug purchases for those on medicare. The measure was opposed by current President George Bush but has saved large pots of money for the US Veterans Health Administration.

Mandatory insurance for children also appears likely. It's widely anticipated that the State Children's Health Insurance Program, which was ratcheted down by Bush, will be significantly expanded to cover more children when it comes up for renewal in March. "It's the perfect place to start," because it has bipartisan support in Congress, says Rachlis.

Broader reform, though, is likely to come far more slowly, says Sloan. Until then, the US can be expected to spend far more on health care than Canada. In 2006, per-capita spending in Canada was US $\$ 3678$ as compared to a hefty $\$ 6714$ in the US, according to the Organisation for Economic Cooperation and Development.

"In Canada, you've got it," says Sloan. "Though it's a different political environment."

But for Jackson, change can't come fast enough. "I don't want anyone to go through what I had to," he says. "The question is how can we do that? How can we fix this broken system?" Katie Lewis, Chicago, Ill.

DOI:10.1503/cmaj.081870

\title{
Ex-provincial health minister sees red
}

$\mathrm{T}$ he rash is gone. The wrath, however, remains. Last fall, Jim Wilson, a former Ontario health minister, was asked to pay $\$ 125$ to make an appointment with his dermatologist to deal with a persistent rash under his arm.

The Conservative MPP (SimcoeGrey) bristled at the notion and told the dermatologist's receptionist that the charge was illegal. He asked her to remind the doctor "that I'm a former minister of health."

That argument had no effect. Wilson, in turn, declined to pay the $\$ 125$. Like millions of other Canadians, he doesn't have a family doctor. His retired about 4 years ago, and Wilson says he hasn't had time to line up for another.

When Wilson called the Ontario Ministry of Health about the charge, he was advised to obtain a referral letter from a walk-in clinic or emergency ward. He also called the College of Physicians and Surgeons of Ontario, though he didn't make a written complaint, which is necessary to trigger a formal investigation.

"I didn't want to embarrass the doctor," Wilson explained. "I just don't want people paying fees that are illegal ... I have elderly constituents who told me they would just pay the fee because they didn't know it was illegal."

Extra charges are increasingly being introduced at private clinics that offer publicly insured services (CMAJ 2008; 179[11]:1112-3), while advocacy groups report that more and more patients report concerns about physician charges (CMAJ 2008; 179[9]:888-9).

Wilson raised the issue in the Ontario legislature "on behalf of the 800000 to 1 million Ontarians who don't have a family doctor and can't get a legitimate

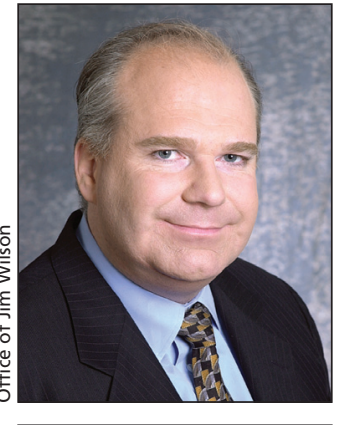

Conservative MPP Jim Wilson. done? "Physicians need to be reminded by the ministry ... probably through the CPSO [College of Physicians and Surgeons of Ontario], that the rules are the rules and if you are this hard up for money, come and talk to us - don't break the Canada Health Act."

The college declined to comment on Wilson's complaint, but a spokesperson says it will sometimes advise physicians if they are not in accord with college policy and will also refer information received about "aberrant billing" to the Ontario Health Insurance Plan. College policy (www.cpso.on.ca/policies/block fees.htm) states that "fees for being available to render an insured service" may not be charged.

Canadian Dermatology Association spokesperson and Toronto-based dermatologist Dr. Charles Lynde has heard of such fees being charged, particularly by doctors who also perform uninsured cosmetic procedures. The fee may be refunded if the visit turns out to be for an insured service, he adds. "It is a grey area ... every physician does what he thinks is right." Lynde says Wilson was " trying to queue jump" and should have "done what the rest of the world does and go see a walk-in clinic." Specialists in Ontario are paid less for an initial visit (a "consultation") if there is no referral letter, he added.

Under Ontario's 2005 Commitment to the Future of Medicare Act, the general manager of the health insurance plan is authorized to require doctors to submit information about extra charges to patients, including "unauthorized" payments. Violations have included charges for medical supplies, such as bandages and syringes, that are included as part of an insured physician service, letter." Health and Long-Term Care Minister David Caplan responded that "I find it remarkable that this member and his party, who advocated a $\$ 3$ billion cut to health care, would even deem to ask this question."

What does Wilson think ought to be and block fees that include some insured services.

The number of reported violations climbed to 320 in 2007/08 from 120 in 2004/05. — Ann Silversides, CMAJ

DOI:10.1503/cmaj.081872 